\title{
Species composition of glass eels (Anguilla spp.) recruiting to the Palu River, Central Sulawesi
}

\author{
[Komposisi spesies glass eels (Anguilla spp.) yang beruaya di muara Sungai Palu, \\ Sulawesi Tengah] \\ Novalina Serdiati ${ }^{1, \bowtie}$, Samliok Ndobe $^{1}$, Abigail Moore ${ }^{2}$, Deddy Wahyudi ${ }^{2}$ \\ ${ }^{1}$ Aquaculture Study Program, Faculty of Animal Husbandry and Fisheries, Tadulako University (UNTAD), \\ ${ }^{2}$ Fisheries and Marine Science Institute (STPL) \\ Aquaculture Study Program, Faculty of Animal Husbandry and Fisheries, Tadulako University (UNTAD), \\ Kampus Bumi Tadulako, Palu 94118, Central Sulawesi \\ Surel: novaserdiati@yahoo.co.id
}

Diterima: 4 Oktober 2012; Disetujui: 5 November 2013

\begin{abstract}
Demand for tropical eel seed has been increased and many tropical eel populations are under pressure. To conserve eel biodiversity and manage eel populations sustainably, it is necessary to identify eel species and their recruitment patterns at regional and watershed scales. The research objective was to determine the species composition and temporal recruitment patterns of glass eels recruiting to Palu River in Central Sulawesi. Glass eels sampling were conducted in JanuaryApril 2009, May-November 2010 and April-December 2011. Identification under anaesthetic (15-17.5 ppm clove oil solution) was based mainly on the number of ano-dorsal vertebrae (ADV). Species composition was dominated by two commercially species, Anguilla marmorata and A. bicolor pacifica with substantial variation and no clear temporal patterns. Specimens of other species that important from conservation and biodiversity aspects were present at each month but cannot be accurately identified using the ADV method. DNA analysis method is required to identify these specimens.
\end{abstract}

Keywords: Anguilla marmorata, Anguilla bicolor pacifica, anodorsal vertebrae, species identification.

\begin{abstract}
Abstrak
Permintaan benih ikan sidat tropis meningkat dan banyak populasi sidat tropis telah mengalami tekanan. Untuk melestarikan keanekaragaman hayati ikan sidat dan mengelola populasi sidat secara berkelanjutan, perlu identifikasi spesies maupun pola rekrutmennya pada skala regional maupun daerah aliran sungai. Tujuan penelitian adalah menentukan komposisi jenis dan pola rekrutmen glass eels secara temporal di Sungai Palu, Sulawesi Tengah. Sampling dilakukan pada bulan Januari-April 2009, Mei-November 2010, dan April-Desember 2011. Identifikasi contoh ikan dalam keadaan pingsan (menggunakan larutan minyak cengkeh 15-17.5 ppm) terutama didasarkan pada jumlah anodorsal vertebrae (ADV). Komposisi jenis didominasi oleh dua spesies bernilai ekonomis, yaitu Anguilla marmorata dan Anguilla bicolor pacifica, namun sangat bervariasi tanpa pola musiman atau tahunan yang jelas. Setiap bulan terdapat beberapa spesimen dari spesies lain, yang penting dari aspek konservasi dan biodiversitas, namun tidak dapat diidentifikasi secara pasti dengan metode ADV. Untuk mengidentifikasi spesimen tersebut dibutuhkan metode analisa genetik (DNA).
\end{abstract}

Kata penting: Anguilla marmorata, Anguilla bicolor pacifica, anodorsal vertebrae, identifikasi spesies.

\section{Introduction}

Freshwater eels (Genus Anguilla) are a valuable fisheries commodity, extensively traded globally (Silfvergrip 2009). All eels of this genus have an unusual catadromous lifecycle, making a one-way spawning migration to deep ocean waters, their larvae carried by ocean currents and recruit to freshwater habitats as glass eels (Tesch 2003). A simple model of the freshwater eel lifecycle including the major causes of eel mortality during their various life stages is shown in Figure 1.

Market demand for eels is high, and eel experts from around the world expressed their concern at the worldwide decline in eel stocks in the Québec Declaration of Concern at the 2003 International Eel Symposium (Fisheries Forum 2003). Despite intensive research and some notable successes (Lockman \& Young 2000, Tanaka et al. 2003, Palstra \& van den Thillart 


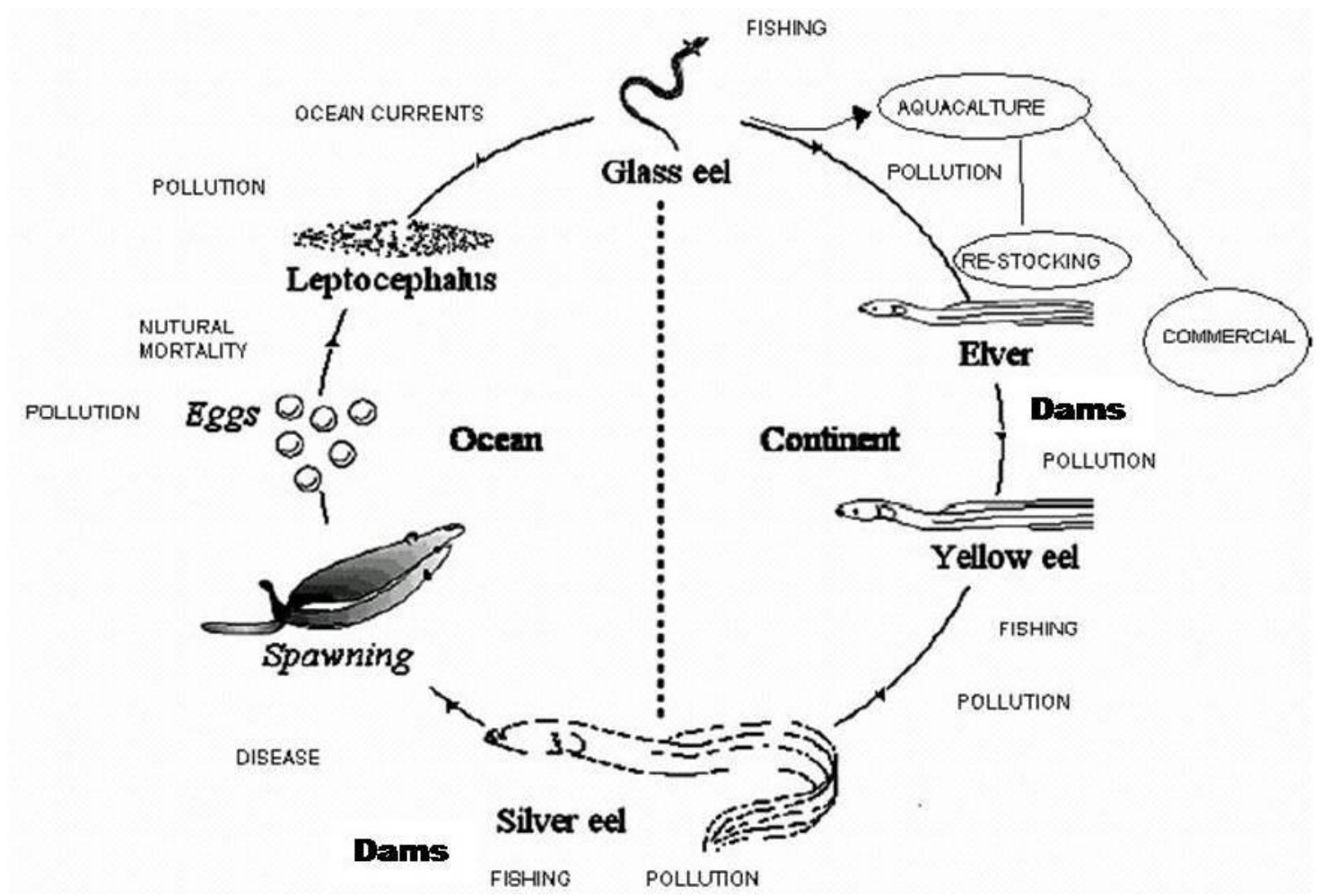

Source: adapted from Liangming et al., 2007

Figure 1. Conceptual model of the eel lifecycle and major causes of mortality

2009, Oliveira 2010), captive breeding is still at the experimental stage and freshwater eel aquaculture worldwide is therefore totally reliant on wild-caught seed. The European eel Anguilla anguilla is considered critically endangered by the International Union for the Conservation of Nature (IUCN) Red List, and has been listed in CITES Appendix II since 2007 (Freyhof \& Kottelat 2010). In response to the growing concern over freshwater eel stocks, exploitation of Anguilla japonica in Japan and A. rostrata in the USA have also come under increasingly strict regulation.

The ongoing need for glass eels to supply the eel grow out industry resulted in an increasing demand for tropical eel seed, including indonesian glass eels. Many tropical eel stocks are now exploited from glass eel to silver eel stage as well as suffering from habitat degradation (Casselman \& Cairns 2009, ICES 2010). The Indonesian Government had long issued (little known) restrictions on the export of eel seed, however in 2009 new legislation was promulgated banning the export of eel seed, with the avowed aim of encouraging the development of incountry aquaculture (grow out). Under this regulation (Peraturan Menteri Kelautan dan Perikanan Republik Indonesia Nomor Per. 18/Men/2009 tentang Larangan Pengeluaran Benih Sidat (Anguilla spp.) dari Wilayah Negara Republik Indonesia ke Luar Wilayah Negara Republik Indonesia), eel seed is defined as "small eels with a length up to $35 \mathrm{~cm}$ and/or a weight of up to $100 \mathrm{~g}$ and/or a diameter up to 2.5 $\mathrm{cm} "$. This definition covers the glass eel stage through to yellow eels which may be several years old.

There are 19 currently recognized species of freshwater eel (Minegishi et al. 2009). Indonesia is widely recognized as the center of anguillid eel diversity and unlike temperate eels, tropical eel species tend to have overlapping distributions 
(Aoyama 2009). Glass eels are known to recruit in multispecies schools to many tropical rivers, including several rivers around the island of Sulawesi, and to exhibit marked seasonal differences in species composition (Arai et al. 1999, Sugeha et al. 2001, Muchsin et al. 2002, Amir et al. 2010).

This diversity is a challenge for aquaculture as from an economic viewpoint the efficient grow-out of glass eels requires mono-species seed of commercially valuable species. It is therefore important to identify freshwater eel species at the glass eel stage, preferably in live condition. The freshwater eel identification key developed to assist in the implementation of CITES regulations for $A$. anguilla (Silfvergrip 2009) described a number of external morphological characteristics, none of which were suitable for determining the species of live glass eels. Genetic methods available at the time would be capable of distinguishing between species at any stage in the life cycle, but were considered unsuitable for sorting large numbers of live glass eels; despite considerable advances such as the semi-multiplex PCR since developed by Fahmi et al. (2013), genetic methods are still not applicable for this purpose.

It is clear that to conserve eel biodiversity and manage Indonesian eel resources sustainably, species distribution and recruitment patterns need to be identified at regional and watershed scales. Indeed, a strategy for eel resource use in Indonesia developed by Affandi (2005) stated that identification of eel resources should be a priority. At a regional level, larvae (leptocephali) of four species (Anguilla marmorata, A. celebesensis, A. borneensis and A. bicolor pacifica) had been reported in the Makassar Straits (Aoyama et al. 2003, Miller 2009, Wouthuyzen et al. 2009).
Glass eels were known to recruit to the Palu River, flowing into Palu Bay, which opens onto the Makassar Straits; however there were no data available on the species composition of eels recruiting to this river.

The main research objective of this multiyear research program which began in 2009 was to determine the species composition and temporal recruitment patterns of glass eels recruiting to Palu River. In order to promote sustainable use, in particular efficient and responsible aquaculture, an identification method was required that could not only identify glass eels but also sort them to provide live and healthy mono-species eel seed of commercially valuable species. Initial results of identification and sorting method development as well as glass eel composition were reported in Ndobe et al. (2010). This paper presents a summary of results to the end of 2011.

\section{Materials and methods}

Glass eels recruiting to the Palu River estuary were sampled in January-April 2009, MayNovember 2010 and April-December 2011. The location of Palu Bay and the Palu River are shown in Figure 2.

Collection using hand-held scoop nets took place at night on a rising tide during the dark/new moon phase (day 28-02 of the lunar cycle). Before and after identification the glass eels were kept in 100 litre aquaria with aeration, filled with 40 litres of water and provided with shelter (piles of small river rocks). Anesthesia of the glass eels during the identification process followed the protocol using a 15-17.5 ppm solution of clove oil developed during 2009/2010 (Ndobe et al. 2010).

Identification was based mainly on the anodorsal vertebrae count (ADV) method de- 

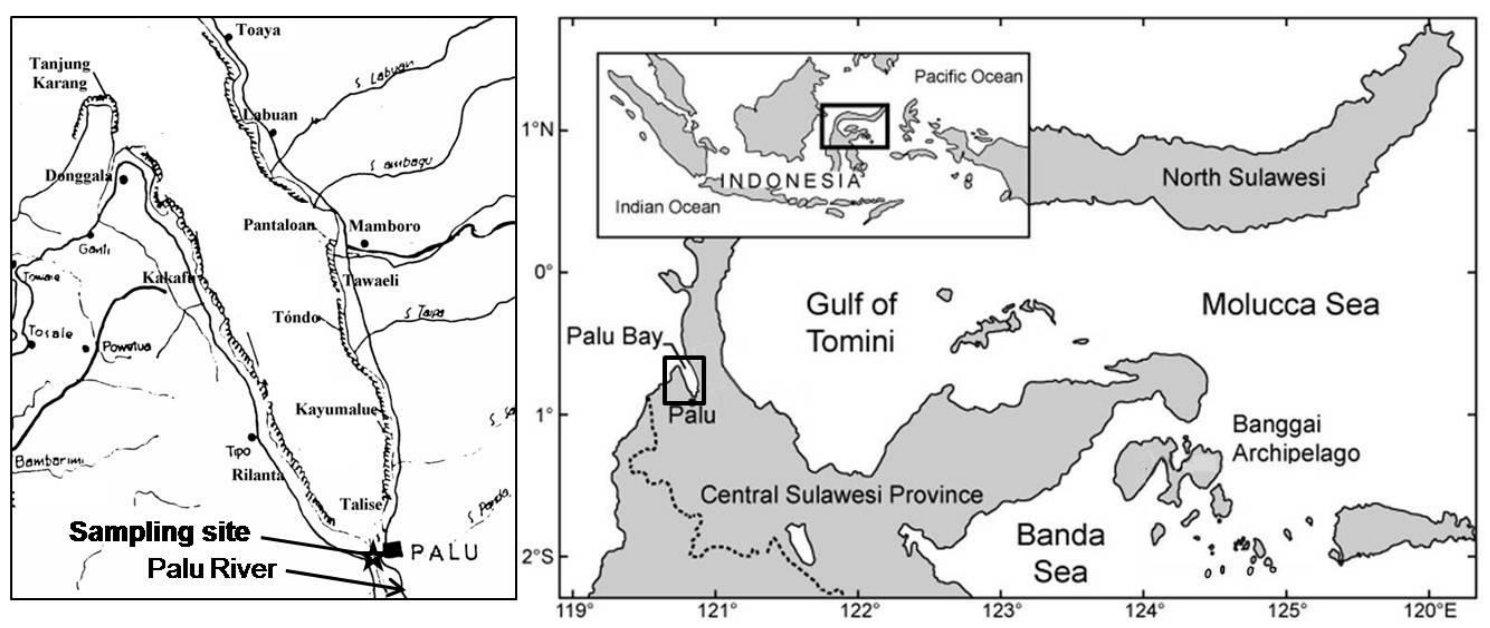

Figure 2. Map showing the location of Palu Bay, Palu River and the sampling site
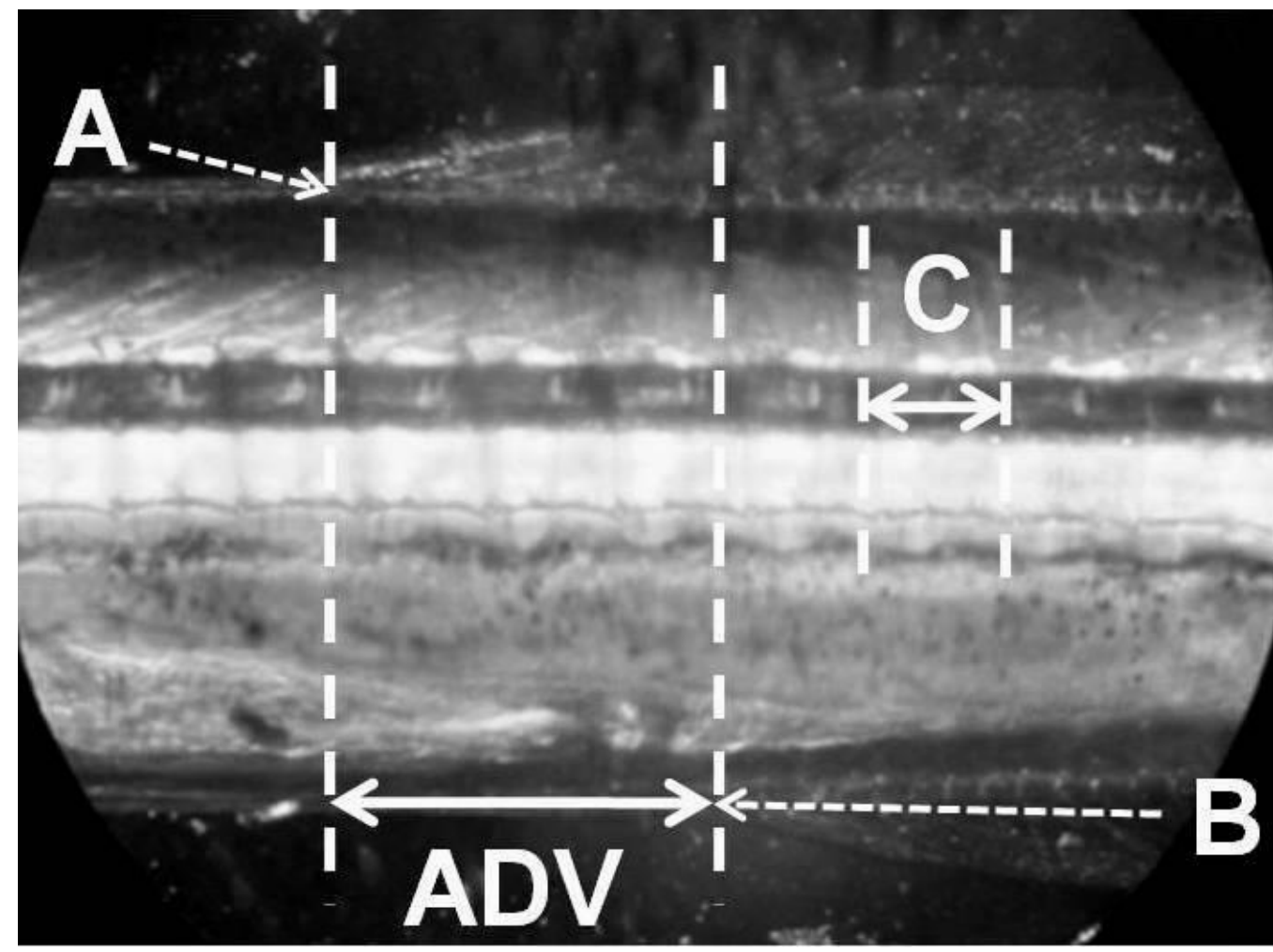

A: root of the dorsal fin; B: root of the anal fin; C: one vertebra; ADV: vertebrae to be counted to obtain the ano-dorsal vertebrae count. Note: in this specimen $\mathrm{ADV}=3$

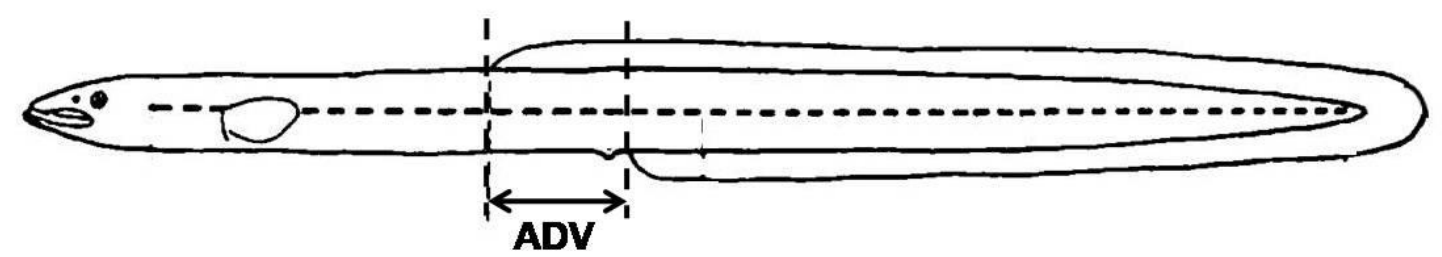

Figure 3. Determining the ADV count 
Table 1. ADV counts for four eel species and ADV categories used

\begin{tabular}{lccc}
\hline \multicolumn{2}{c}{$\begin{array}{c}\text { ADV counts based on Tabeta } \text { et al. (1976a) and } \\
\text { Silfvergrip (2009) }\end{array}$} & \multicolumn{2}{c}{$\begin{array}{c}\text { ADV categories } \\
\text { used in this research }\end{array}$} \\
\hline \multicolumn{1}{c}{ Species } & ADV Count & A. marmorata & ADV Count \\
\hline A. marmorata & 13 to 18 & A. bicolor pacifica & $\leq 13$ \\
A. bicolor pacifica & -6 to +3 & Anguilla spp. $*$ & $\leq 4$ \\
A. celebesensis & 6 to 12 & & 6 to 12 \\
A. borneensis & 7 to 12 & & \\
\hline
\end{tabular}

* Specimens with ADV values in the 6-12 range cannot be identified based on ADV and were therefore categorised as Anguilla spp.
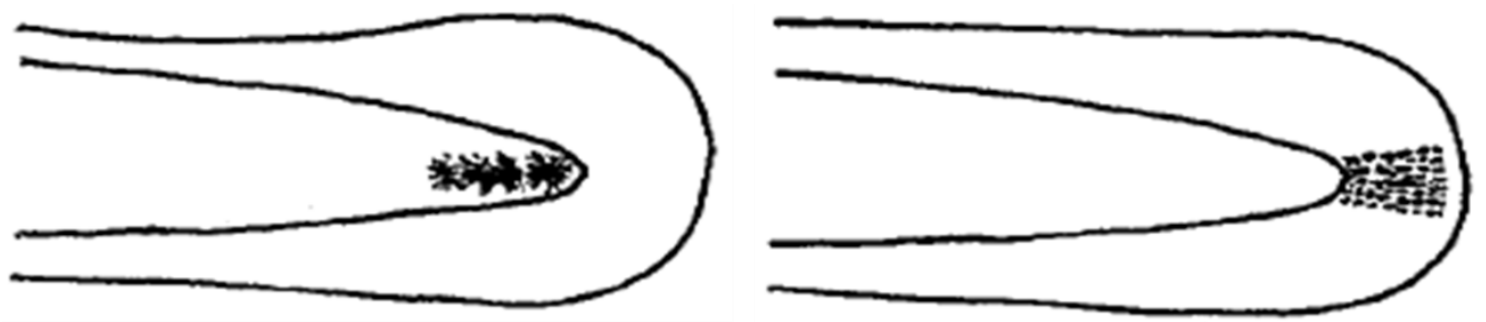

Figure 4. Tail Spot (TS) shapes of A. marmorata/A. celebesensis (left) and A. bicolor pacifica (right) according to Tabeta et al. (1976b)

scribed in Tabeta et al. (1976a). The number of anodorsal vertebrae (between the root of the anal fin and the dorsal fin) can be used to distinguish between species or species groups as shown in Table 1. In the glass eel stage, the body is still transparent, so that the vertebrae could be seen and counted as shown in Figure 3. A binocular microscope with 20 times magnification was used.

Although the ADV method is effective, it requires considerable resources in terms of time, trained personnel and equipment. A second method was developed to provide a faster, simpler method for larger-scale glass eel identification and sorting. During metamorphosis from transparent glass eel to pigmented benthic elver, melanophores are first formed in the head and tail regions (Usui 1976). The melanophores in the tail area are called the caudal spot or tail spot (TS), the shape of which varies between species (Silvfergrip 2009). The tail spot shapes of $A$. marmorata/A. celebesensis and A. bicolor paci- fica glass eels according to Tabeta et al. (1976b) are shown in Figure 4. Tail spots were observed under anesthetic using a binocular microscope and a variety of magnifying glasses.

The ADV data were tabulated and analyzed graphically. Tail Spot (TS) data were analyzed descriptively and compared with ADV data to evaluate the accuracy of the TS method using the various magnifying glasses obtained. A concordance rate of $95 \%$ or higher was considered to be acceptable.

\section{Results}

\section{Anodorsal vertebrae (ADV) count}

The overall ADV composition of glass eels sampled is shown in Figure 5. Species identification data using the ADV method are shown in Table 2. The monthly species composition for 2011 is shown in Figure 6. The percentage of each species or species group by month and year are shown in Figure 7. 
Just over half of the total sample (51.15\%) were identified as Anguilla marmorata (ADV $\geq$ 13). This was the dominant species in 10 out of 20 months, and A. marmorata glass eels were present every month although sometimes in very low numbers. Over one third $(35.86 \%)$ of the total sample were identified as A. bicolor paci- fica $(\mathrm{ADV} \leq 4)$. This was the dominant species in eight out of the twenty months and was not present in only one month (April 2011). Numbers were also very low (less than 10 specimens) in four other months (July, September and October 2010 and May 2011).

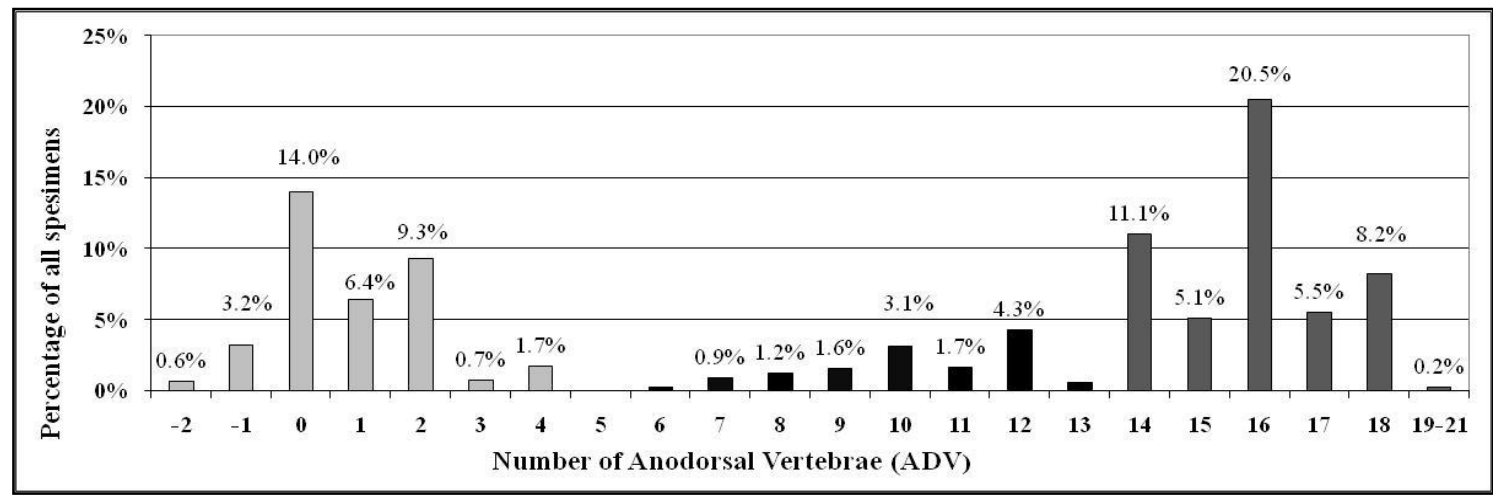

Figure 5. Overall ADV distribution of glass eels recruiting to the Palu River sampled in January-April 2009, May-November 2010 and April-September 2011

Table 2. Species composition of glass eels recruiting to the Palu River estuary

\begin{tabular}{cccccccc}
\hline $\begin{array}{c}\text { Month/ } \\
\text { Year }\end{array}$ & \multicolumn{2}{c}{$\begin{array}{c}\text { A. marmorata } \\
\text { ADV } \geq 13\end{array}$} & \multicolumn{2}{c}{$\begin{array}{c}\text { A. bicolor pacifica } \\
\text { ADV } \leq 4\end{array}$} & \multicolumn{2}{c}{$\begin{array}{c}\text { Anguilla spp. } \\
\text { ADV 6-12 }\end{array}$} & $\begin{array}{c}\text { Number of } \\
\text { glass eels }\end{array}$ \\
& number & $\%$ & number & $\%$ & number & $\%$ & Sampled \\
\hline $01 / 09$ & 12 & 3.93 & 288 & 94.43 & 5 & 1.64 & 305 \\
$02 / 09$ & 91 & 26.22 & 252 & 72.62 & 4 & 1.15 & 347 \\
$03 / 09$ & 248 & 79.23 & 50 & 15.97 & 15 & 4.79 & 313 \\
$04 / 09$ & 109 & 89.34 & 10 & 8.20 & 3 & 2.46 & 122 \\
$05 / 10$ & 196 & 88.69 & 20 & 9.05 & 5 & 2.26 & 221 \\
$06 / 10$ & 81 & 36.32 & 133 & 59.64 & 9 & 4.04 & 223 \\
$07 / 10$ & 151 & 78.65 & 6 & 3.13 & 35 & 18.23 & 192 \\
$08 / 10$ & 210 & 86.42 & 27 & 11.11 & 6 & 2.47 & 243 \\
$09 / 10$ & 196 & 90.32 & 8 & 3.69 & 13 & 5.99 & 217 \\
$10 / 10$ & 212 & 94.64 & 4 & 1.79 & 8 & 3.57 & 224 \\
$11 / 10$ & 96 & 41.56 & 130 & 56.28 & 5 & 2.16 & 231 \\
$04 / 11$ & 99 & 46.3 & 0 & 0 & 115 & 53.7 & 214 \\
$05 / 11$ & 69 & 30.4 & 4 & 1.8 & 154 & 67.8 & 227 \\
$06 / 11$ & 178 & 73.9 & 36 & 14.9 & 27 & 11.2 & 241 \\
$07 / 11$ & 170 & 77.0 & 28 & 13.0 & 23 & 10.0 & 221 \\
$08 / 11$ & 459 & 79.0 & 12 & 2.0 & 112 & 19.0 & 583 \\
$09 / 11$ & 15 & 4.0 & 335 & 95.0 & 2 & 1.0 & 352 \\
$10 / 11$ & 56 & 18.1 & 210 & 68.0 & 43 & 13.9 & 309 \\
$11 / 11$ & 39 & 14.2 & 148 & 53.8 & 88 & 32.0 & 275 \\
$12 / 11$ & 3 & 1.5 & 185 & 92.5 & 12 & 6.0 & 200 \\
\hline Overall & 2690 & 51.15 & 1886 & 35.86 & 683 & 12.99 & 5259 \\
\hline
\end{tabular}




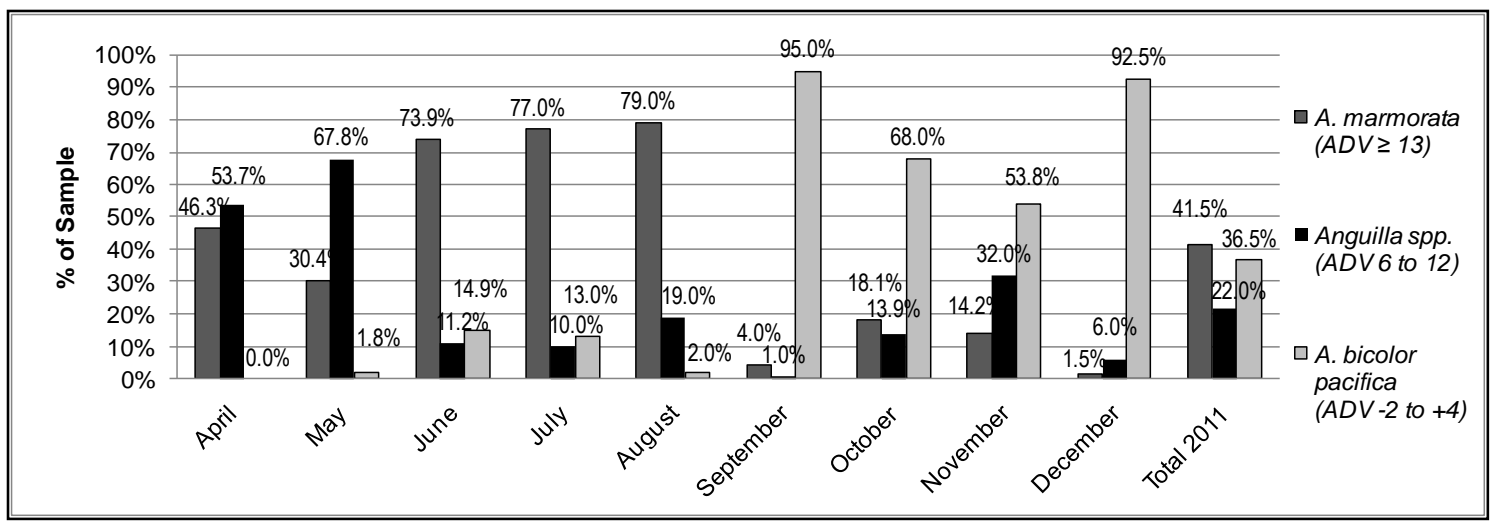

Figure 6. Monthly glass eel species composition (ADV) in 2011

Table 3. Specimens with ADV counts in the 6-12 range by month/year

\begin{tabular}{cccccccc}
\hline Month/year & 6 & 7 & 8 & 9 & 10 & 11 & 12 \\
\hline $01 / 09$ & 0 & 0 & 0 & 3 & 0 & 0 & 2 \\
$02 / 09$ & 0 & 0 & 0 & 1 & 1 & 0 & 2 \\
$03 / 09$ & 0 & 0 & 2 & 5 & 8 & 0 & 0 \\
$04 / 09$ & 0 & 0 & 0 & 1 & 0 & 2 & 0 \\
$05 / 10$ & 0 & 1 & 0 & 0 & 2 & 1 & 1 \\
$06 / 10$ & 0 & 1 & 0 & 1 & 4 & 1 & 2 \\
$07 / 10$ & 0 & 0 & 3 & 11 & 14 & 6 & 1 \\
$08 / 10$ & 0 & 2 & 1 & 0 & 0 & 1 & 2 \\
$09 / 10$ & 0 & 0 & 0 & 0 & 6 & 0 & 7 \\
$10 / 10$ & 0 & 0 & 0 & 0 & 4 & 0 & 4 \\
$11 / 10$ & 0 & 0 & 0 & 2 & 2 & 0 & 1 \\
\hline $2009 / 10$ & 0 & 4 & 6 & 24 & 41 & 11 & 22 \\
$\%$ & $0.0 \%$ & $3.7 \%$ & $5.6 \%$ & $22.2 \%$ & $38.0 \%$ & $10.2 \%$ & $20.4 \%$ \\
\hline $04 / 11$ & 1 & 4 & 14 & 22 & 35 & 12 & 27 \\
$05 / 11$ & 0 & 16 & 31 & 17 & 53 & 9 & 28 \\
$06 / 11$ & 0 & 1 & 7 & 0 & 9 & 0 & 10 \\
$07 / 11$ & 0 & 0 & 0 & 0 & 9 & 0 & 14 \\
$08 / 11$ & 0 & 0 & 0 & 0 & 20 & 0 & 92 \\
$09 / 11$ & 0 & 2 & 0 & 0 & 0 & 0 & 0 \\
$10 / 11$ & 0 & 15 & 4 & 0 & 0 & 0 & 24 \\
$11 / 11$ & 0 & 13 & 1 & 0 & 19 & 0 & 55 \\
$12 / 11$ & 0 & 3 & 0 & 0 & 0 & 0 & 9 \\
\hline 2011 & 1 & 54 & 57 & 39 & 145 & 21 & 259 \\
$\%$ & $0.2 \%$ & $9.4 \%$ & $9.9 \%$ & $6.8 \%$ & $25.2 \%$ & $3.6 \%$ & $45.0 \%$ \\
\hline
\end{tabular}

The intermediate (6-12) ADV range specimens (Anguilla spp.) were present every month, but only dominant in two months (April and May 2011). Present in very low numbers (under 6\%) in all but one (July 2010, 18.23\%) month sampled in 2009/2010, the majority (82\%) were collected in 2011 with very low numbers in two months (September and December). The monthly ADV values of specimens in this category are shown in Table 3, while aggregate values for 2009/10 and 2011 are shown in Figure 8.

The composition of glass eels recruiting to the Palu River exhibited significant seasonal variation within each year, and significant interannual variation in overall and seasonal species composition as well as in the recruitment patterns of each species or species group. In addition, the data in Table 3 and Figure 8 reveal a high level of variability in distribution within the ADV 6-12 

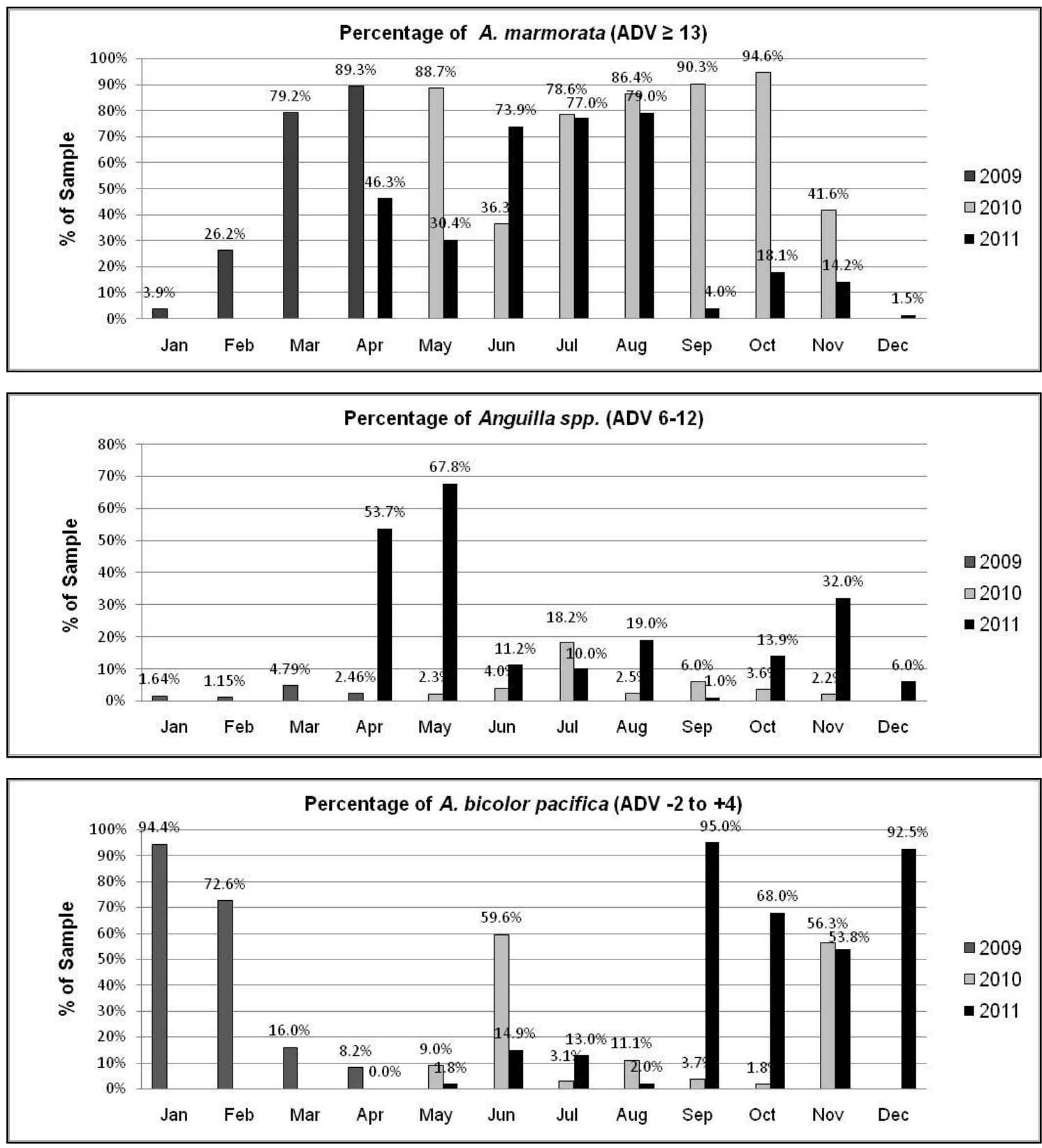

Figure 7. Percentage of each species/ADV category by month and year

range between sampling periods (months/years). Within this group, all values from 6 to 12 were observed. The dominant ADV count in 2009/10 was 10 , followed by 9 and 12; in 2011, ADV 12 was dominant, comprising nearly half the sample (45\%) followed by ADV 10.

\section{Tail spot (TS) shape}

The tail spot shapes given in Tabeta et al. (1976b) are for A. bicolor (broom or brush shaped) and for the two species A. marmorata and A. celebesensis (arrow shaped) as shown in Figure 4. It was therefore expected that the tail spot of the latter two species would be the same or very similar. In 2009 and 2010, there were very few specimens with ADV counts of 6-12, of which at least a proportion would be expected to be A. celebesensis. In order to check the assumption regarding tail spot shape, glass eels were obtained from the Poso River where the dominant species are A. marmorata and A. celebesensis. A sketch of the tail spot of A. celebesensis glass 
eels from Poso River, which differed from that of the A. marmorata specimens, is shown in Figure 9.

The tail spots of most Anguilla spp. glass eels from the Palu River were similar to Figure 9. This can be seen in photographs of Anguilla spp.,
A. marmorata and A. bicolor pacifica tail spots taken with a digital camera using macro function directly (Figure 10) and via the microscope ocular (Figure 11).

To replace the binocular microscope used in Figure 11, the first suitable magnifying glass

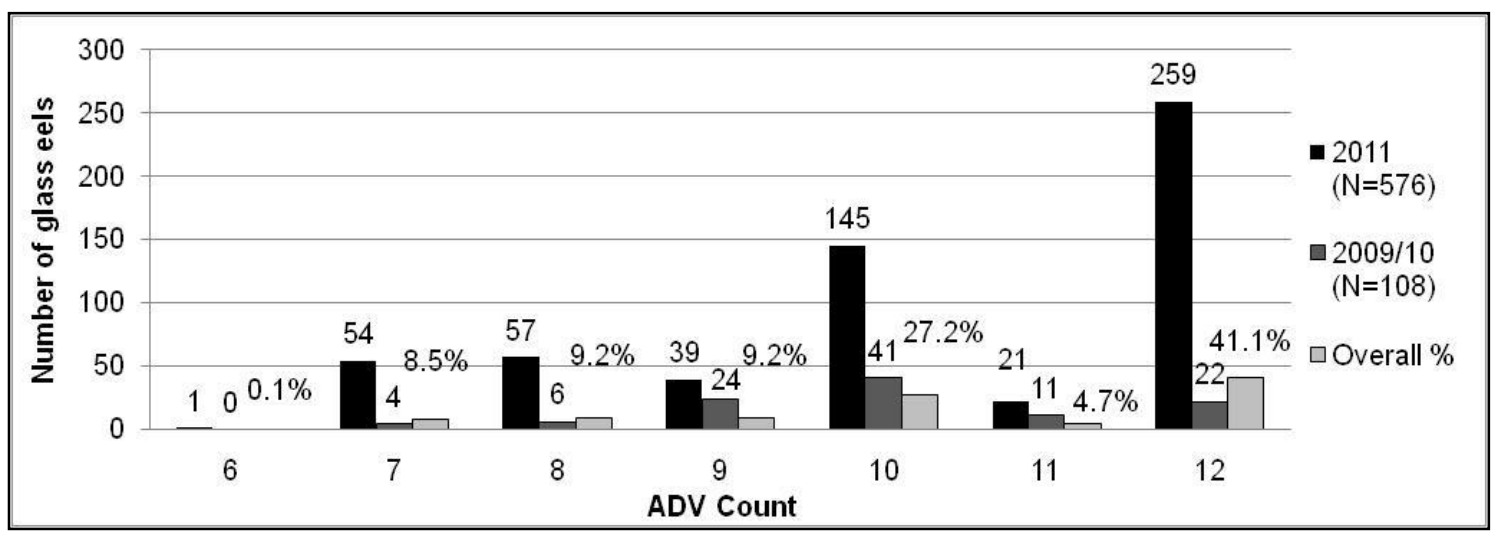

Figure 8. ADV distribution of Anguilla spp. (ADV 6-12) sampled

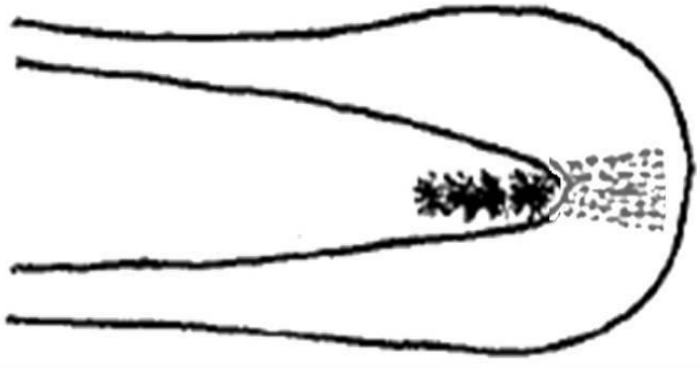

Note: arrow shaped melanophores over terminal vertebrae similar to A. marmorata; "broom" shape similar to but generally somewhat paler and less dense (bushy) than in A. bicolor pacifica and sometimes somewhat ragged at the rear (outer) edge

Figure 9. Sketch of the tail spot (TS) of Anguilla celebesensis glass eels
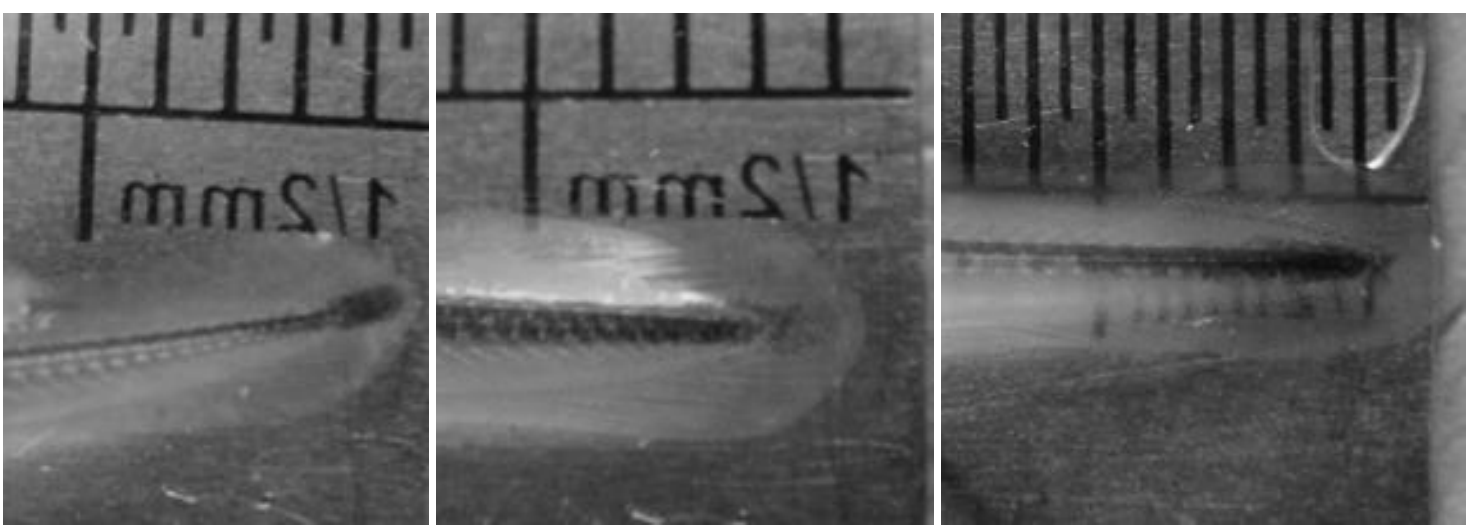

Left: A. bicolor pacifica; Centre: Anguilla spp.; Right: A. marmorata

Figure 10. Photographs of glass eel tail spots (digital camera "macro" settings) 


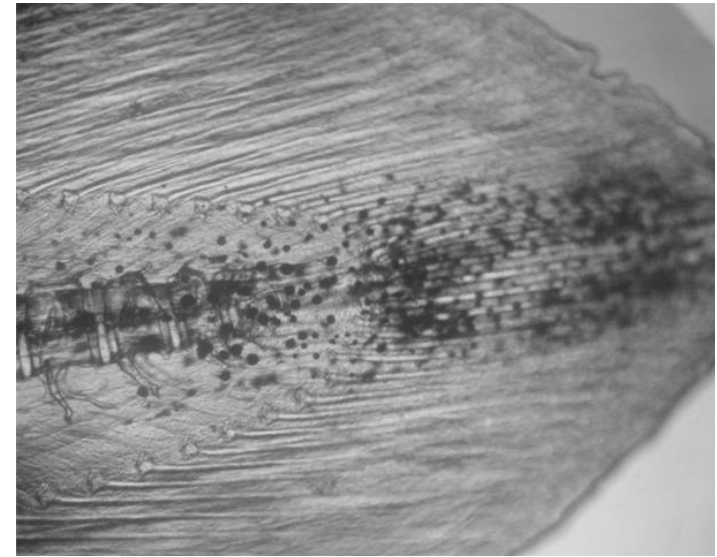

Anguilla bicolor pacifica tail spot

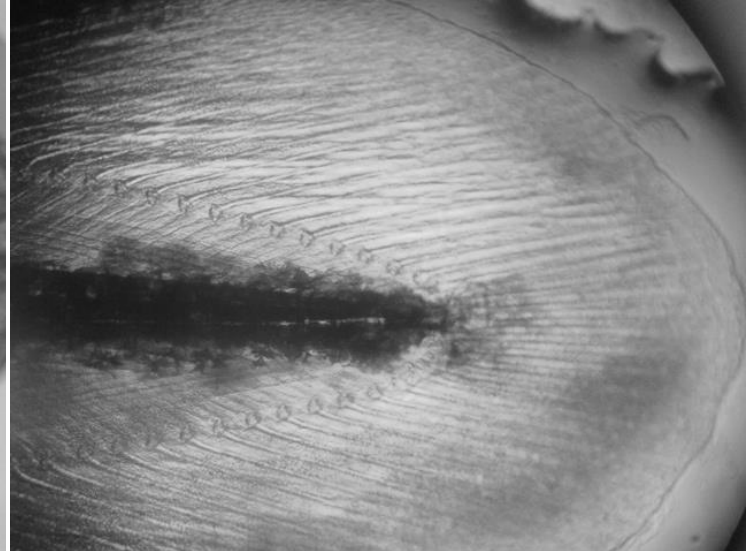

Anguilla marmorata tail spot
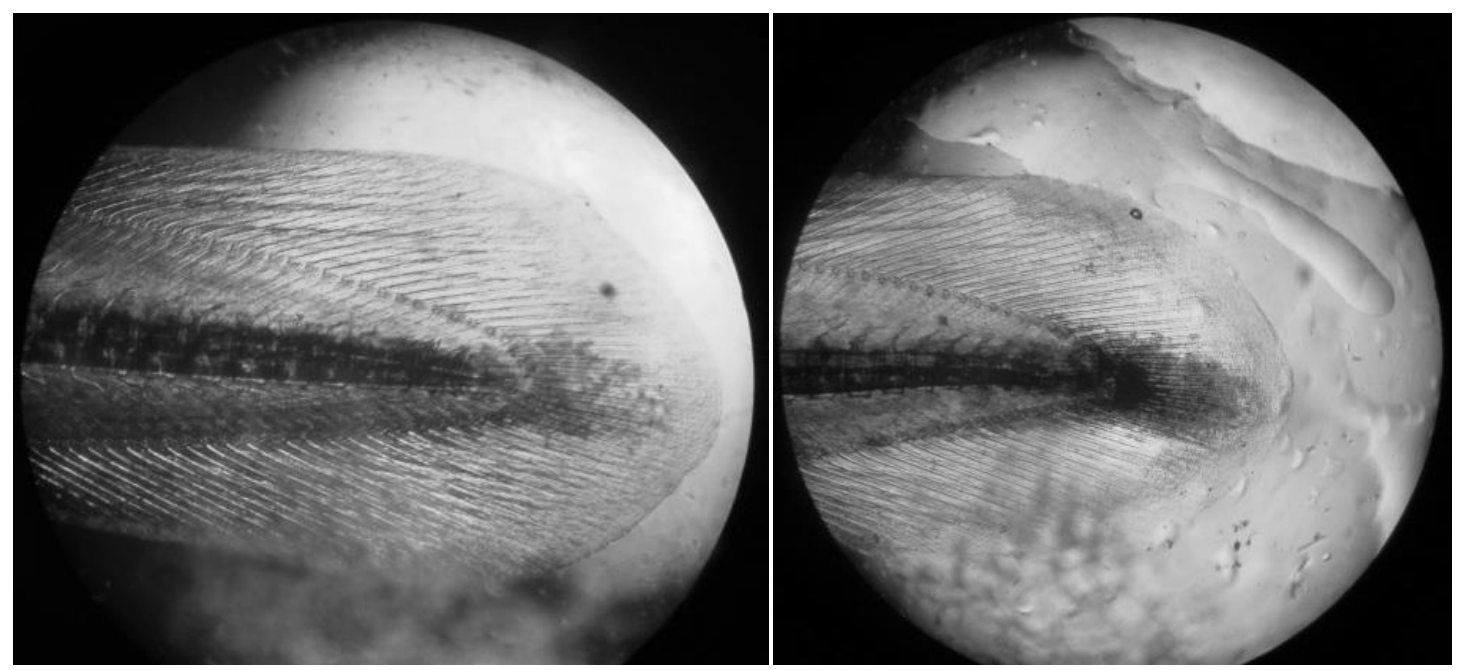

Anguilla spp. tail spot with "arrow" and "brush" - two examples

Figure 11. Examples of glass eel tail spots from Palu River

identified was an antique biologist's field glass with a secondary magnification blister. This enabled the observer to view tail spots with a resolution similar to that shown in Figure 10. Available modern alternatives were tested with the help of student volunteers, trials which also addressed a second challenge which is assessing whether the skill in identification acquired by the researchers could readily be transferred. These trials showed that monocles produced for use in watch repair (rated as X 4 and X 5 magnification respectively) could provide similar resolution to the antique field glass and results consonant with the use of the binocular microscope (X 20 magnification).
The TS method applied to glass eels from Palu River was $100 \%$ accurate in separating shortfin eels (A. bicolor pacifica) from long fin eels (all other species likely to be found in the area). In separating $A$. marmorata $(\mathrm{ADV} \geq 13$ ) from other long-fin (ADV 6-12) glass eels during 2009 and 2010, the TS method was over $95 \%$ consonant with ADV counts and considered acceptable. The few misidentifications were mostly A. marmorata (ADV $\geq 13$ ) identified as Anguilla spp. (ADV 6-12), and errors therefore could be expected to support a precautionary approach form a conservation perspective. However in 2011 there were a considerable number of glass eels in the 6-12 ADV range with tail spots which 
did not conform to the pattern sketched in Figure 9, and the TS identification was less than $95 \%$ consonant with ADV counts.

\section{Discussion}

Species composition dominancy and patterns

During 2009 and 2010, in every sampling month the glass eels recruiting to the Palu River were predominantly A. marmorata and/or $A$. $b i$ color pacifica, with low or very low numbers of glass eels in the 6 to $12 \mathrm{ADV}$ range. This lead to an initial conclusion by Ndobe et al. (2010) that these two economically valuable species, suitable as seed for eel aquaculture activities, each occurred in large numbers but on a seasonal basis, making confirmation of the apparent seasonality of recruitment in each of these species an important prerequisite for the planning and implementation of ecologically and economically sustainable exploitation.

The results of the 2011 sampling put in question many of the initial (tentative) conclusions based on 2009/10 data, in particular regarding species dominance and seasonality. In two months (April and May 2011) the sample was dominated by glass eels in the ADV 6-12 range, and in five other months this group constituted more than $10 \%$ of the sample. A. marmorata numbers were lower (in some cases much lower) than in previous years for all but one month (June) sampled in 2011. In addition, peaks in the recruitment of all species occurred at different times of year in 2011 compared to 2009/2010.

The cause or causes of these inter-annual variations in seasonality and abundance (absolute and relative) are not known, but are likely due to a combination of factors. As discussed in Kuroki et al. (2012) primarily in respect of Anguilla luzonensis (but also A. marmorata, A. celebesensis and A. bicolor pacifica), factors which could in- fluence the recruitment of each eel species include those which affect the survival rate, timing and output (reproductive success) of breeding eels as well as the transport via ocean currents of the eel larvae as leptocephali and throughout the metamorphosis to the glass eel stage.

The spawning grounds supplying glass eels which recruit to the Palu River are not known with certitude, and evaluation of these factors will not be a simple task, even for the two commercially valuable species which between them comprise the majority of the observed cohorts. It is likely that $A$. marmorata glass eels recruiting to the Palu River form part of a panmictic Japan-Sulawesi population based on the genetic analysis by Minegishi et al. (2008), and originate from the spawning ground in the north eastern Pacific Ocean postulated by Miller et al. (2002) and now generally accepted (Righton et al. 2012). The spawning ground(s) of A. bicolor pacifica do not appear to have been identified; however current and species distribution maps in Aoyama (2009) and Fahmi et al. (2102) indicate that both A. marmorata and A. bicolor pacifica appear to recruit to the northern Makassar Straits via the Indonesian Throughflow.

Righton et al. (2012) state that "even today, with the advent of marine remote sensing, genetic and otolith analyses, electronic tagging, and investigative computer modelling, there are many fundamental questions about Anguilla spp. migrations that remain unanswered". They furthermore postulate that eel migrations are and may be increasingly affected by climate-related factors. In particular that the survival and migration routes of eel larvae could be affected by multi-decadal trends in ocean circulation as well as changing current patterns due to climate change. It is possible that there are temporal patterns in glass eel recruitment to the Palu River 
over time periods of several years or even decades which cannot be detected based on the short time-frame of existing data. It is also possible that patterns are changing or will change due to global shifts in climate and oceanic circulation.

\section{Species composition of the 6-12 ADV range}

There are at least three tropical eel species now known to have between 6 and 12 ano-dorsal vertebrae. These are A. celebesensis, A. borneensis, and A. luzonensis (7-10 ADV, Kuroki et al. 2012) now officially recognized as senior synonym of A. huangi (Watanabe et al. 2013). Leptocephali of both A. celebesensis and A. borneensis have been identified in the Makassar Straits (Wouthuyzen et al. 2009). Although as yet unidentified, available information indicates that the spawning ground of $A$. borneensis is most likely in or near to the Makassar Straits.

The known spawning ground of A celebesensis is in Tomini Bay (Aoyama et al. 2003). It is not impossible that larvae could, at least on a seasonal or occasional basis, be carried out of the bay by currents which would eventually join the Indonesian Throughflow and thus enter the Makassar Straits. It is also not impossible that, like A. marmorata, A. celebesensis may have more than one spawning ground.

The cryptic species A. luzonensis, morphologically almost undistinguishable from A. celebesensis, was identified in the Philippines through genetic analysis (Watanabe et al. 2009). Research on leptocephali indicates that the spawning ground for this species is close to the north eastern Pacific spawning ground of A. marmorata (Kuroki et al. 2012), allowing the larvae to be entrained in the North Equatorial Current (NEC), the northern branch of which flows to Luzon in northern Philippines where the species was discovered (Watanabe et al. 2009). It is re- markable that the sampling area of Tabeta et al. (1976b) would seem to coincide with the distribution of A. luzonensis reported in Watanabe et al. (2009) and Aoyama (2009). According to Tabeta et al. (1976b), the TS of A. marmorata and $A$. celebesensis are the same (Figure 2, left). Leander et al. (2012) found that the TS of $A$. marmorata and A. luzonensis were indistinguishable, and resembled that described by Tabeta et al. (1976b), and also opined that that A. celebesensis specimens previously reported from Taiwan were most likely misidentified A. luzonensis.

Ndobe et al. (2010) found a difference between the TS of glass eels from the Poso River known to be $A$. marmorata and A. celebesensis and a similar difference was observed in the majority of the ADV 6-12 specimens from the Palu River (Figure 11). It is possible that some of the misidentified glass eels, especially those with TS resembling that of $A$. marmorata, could be $A$. luzonensis. We consider that some leptocephali entrained in the NEC could conceivably be carried towards Sulawesi, join the Indonesian Throughflow, enter the Makassar Straits and hence reach Palu Bay and the Palu River estuary. This would be similar to the migration of $A$. marmorata implicated by the maps in Aoyama (2009) and Fahmi et al. (2012). This migration route would also be consonant with Kuroki et al. (2012) who also consider that historically A. luzonensis glass eels may have been misidentified as A. celebesensis, and furthermore that it is possible A. luzonensis leptocephali might, at least occasionally, be carried by ocean currents to northern Sulawesi.

The ADV 6-12 group, of relatively low economic value at the present time, is considered important from a biodiversity perspective. In view of their low numbers, it was considered important to ensure that as many as possible of the naturally recruiting glass eels survived to mig- 
rate. Therefore, when sorting the two more numerous species to provide mono-species A. marmorata and A. bicolor pacifica eel seed, it should be a priority to separate glass eels of the ADV 612 group and return them to the wild.

The tail spot observations as well as the variability in ADV count distribution within and between months strengthen the contention that there may be more than one species with ADV counts in the 6-12 range recruiting to the Palu River. Furthermore, the size of these glass eels tended to exhibit a seemingly bi-modal distribution rather than the normal (bell curve) distribution of the aggregated A. marmorata and A. bicolor pacifica samples. This could be an artefact of sampling size, especially in the months with a low percentage in this group, however it is also possible that it could be due to the presence of two (or more) species and/or the presence of glass eels of different ages (from different spawning events or even spawning grounds) recruiting at the same time.

As there are at least three species which could possibly recruit to the Palu River with ADV counts in the 6-12 range, it is important from a biodiversity and biogeographical perspective to identify the species actually present. The genomes of all the eels species known or suspected to recruit to the Palu River have been identified and stored in the global DNA/protein database GenBank (Minegishi et al. 2009) and protocols for DNA-based identification of one or several species have now been developed, for example Fahmi et al. (2013). However, in view of observed inter-seasonal and inter-annual variability in recruitment, sample selection would need to cover the full ADV range and several months at least (ideally over a time frame of one or more years) in order to be certain of identifing the full range of species present.

\section{Conclusion}

At least three species recruited to the Palu River during the research period. For 18 out of 20 months, species composition was dominated by Anguilla marmorata and/or A. bicolor pacifica, both commercially valuable species. Specimens of one or more other species which cannot be accurately identified by the methods (ADV and tail spot) used were present each month, dominated the samples collected in two out of 20 months, and are considered important from conservation and biodiversity aspects. Genetic analysis is considered necessary to determine the identity of these glass eels and thus the full species composition of glass eels recruiting to the Palu River.

The ADV method using clove oil as an anesthetic is considered applicative and suitable for sorting small quantities of glass eels, to produce mono-species seed of two commercially valuable species and allow glass eels of non-commercial species to be separated and released back to the wild. The tail spot (TS) method requires further development but shows promise as a lowtechnology, low cost method for separating larger quantities of eel seed.

\section{Acknowledgments}

The authors gratefully acknowledge support in the form of research grants from the Indonesian Higher Education Authority (DIKTI) Strategic National Research (PSN) in 2010 and 2011. The authors also wish to thank all who took part in or supported the research and/or helped to make the compilation and presentation of this paper possible. In particular, the Aquaculture Study Program at Tadulako University, the Fisheries and Marine Science Institute (Sekolah Tinggi Perikanan dan Kelautan), Megawati, Nilmawati, Alismi M. Salanggon, Osmar Buatan, 
Abdul Rahman, Renol, Wulan Yuniarti, Gita

Afriany, Muhammad Muttaqin and, as well as the anonymous reviewers who provided valuable input to improve this paper.

\section{References}

Affandi R. 2005. Strategi pemanfaatan sumber daya ikan sidat Anguilla sp. di Indonesia. Jurnal lktiologi Indonesia, 5(2):77-81. (in Indonesia)

Amir F, Mallawa A, Budimawan, Tresnati J. 2010. Rekrutmen larva ikan sidat (Anguilla spp.) ke Perairan Malunda, Sulawesi Barat. Jurnal Sains dan Teknologi, 10(1):1-6.

Aoyama J. 2009. Life history and evolution of migration in catadromous eels (Anguilla sp.). Aqua-Bio Science Monograph, 2(1):142.

Aoyama J, Wouthuyzen S, Miller MJ, Inagaki T, Tsukamoto K. 2003. Short-distance spawning migration of tropical freshwater eels. The Biological Bulletin, 204(1):104-108.

Arai T, Aoyama J, Limbong D, Tsukamoto K. 1999. Species composition and inshore migration of the tropical eels Anguilla spp. recruiting to the estuary of the Poigar River, Sulawesi Island. Marine Ecology Progress Series, 188:299-303.

Casselman JM, Cairns DK (eds). 2009. Eels at the edge: Science, status, and conservation concerns. American Fisheries Society. Summary. ttp://www.afsbooks.org/54058C [download 06 March 2010]

Fahmi MR, Pouyaud L, Berrebi P. 2012. Distribution of tropical eel Genus Anguilla in Indonesia water based on Semi-Multiplex PCR. Indonesian Aquaculture Journal, 7(2):139-148

Fahmi MR, Solihin DD, Soewardi K, Pouyaud L, Shao Z, Berrebi P. 2013. A novel semimultiplex PCR assay for identification of tropical eels of genus Anguilla in Indonesian waters. Fisheries Science, 79(2):185191

Fisheries Forum 2003. Worldwide decline of eel resources necessitates immediate action: Québec declaration of concern. Fisheries Forum, 28(12):28-30

Freyhof J, Kottelat M. 2010. Anguilla anguilla. In: IUCN 2011. IUCN Red list of threatened species. Version 2011.2. <www.iucnredlist.org>. [Download 12 May 2012]

ICES. 2010. Report of the 2009 session of the Joint EIFAC/ICES Working Group on Eels. Göteborg, Sweden,7-12 September 2009. EIFAC Occasional Paper No. 45. European Inland Fisheries Advisory Commission, International Council for the Exploration of the Sea (ICES). Copenhagen, Denmark.

Kuroki M, Miller MJ, Aoyama J, Watanabe S, Yoshinaga T, Tsukamoto K. 2012. Offshore spawning for the newly discovered anguillid species Anguilla luzonensis (Teleostei: Anguillidae) in the Western North Pacific. Pacific Science, 66(4):497-507.

Leander NJ, Shen KN, Chen RT, Tzeng WN. 2012. Species composition and seasonal occurrence of recruiting glass eels (Anguilla spp.) in the Hsiukuluan River, Eastern Taiwan. Zoological Studies, 51(1):59-71.

Liangming C, Xinyu C, Yu C, Ping F, Yuyu H, Haiyan L, Mingyan L, Cong W. 2007. Eel population and solution model. Roskilde University, UK. 66 p.

Lockman PM, Young G. 2000. Induced spawning and early ontogeny of New Zealand freshwater eels (Anguilla dieffenbachii and A. australis). New Zealand Journal of Marine and Freshwater Research, 34(1):135145.

Miller M, Mochioka N, Otake T, Tsukamoto K. 2002. Evidence of a spawning area of Anguilla marmorata in the western North Pacific. Marine Biology, 140(4):809-814.

Miller MJ. 2009. Ecology of anguilliform leptocephali: Remarkable transparent fish larvae of the ocean surface layer. Aqua-Bio Science Monograph, 2(4):1-94.

Minegishi Y, Aoyama J, Tsukamoto K. 2008. Multiple population structure of the giant mottled eel, Anguilla marmorata. Molecular Ecology, 17(13):3109-3122.

Minegishi Y, Aoyama J, Inoue JG, Azaza RV, Tsukamoto K. 2009. Inter-specific and subspecific genetic divergences of freshwater eels, genus Anguilla including a recently described species, A. luzonensis, based on whole mitochondrial genome sequences. Coastal Marine Science, 33:64-77.

Muchsin I, Zairon, Ndobe S. 2002. Beberapa aspek biologi larva sidat (Anguilla sp.) di muara Sungai Poso, Sulawesi Tengah. In: Badan Pengkajian dan Penerapan Teknologi dan Departemen Perikanan dan Kelautan. 
Prosiding Forum Nasional Sumber Daya Perikanan Sidat Tropik 2002. pp. 78-83.

Ndobe S, Moore A, Serdiati N, Nilmawati. 2010. Glass eels (Anguilla sp.) recruiting to Palu River, Central Sulawesi, Indonesia. Proceedings of the International Conference of Indonesia Aquaculture 2010 (ICAI), 25-28 October 2010, Hang Tuah University, Surabaya, Indonesia.

Oliveira K, Hable W.E. 2010. Artificial maturation, fertilization, and early development of the American eel (Anguilla rostrata). Canadian Journal of Zoology, 88(11):1121-1128.

Palstra A, van den Thillart G. 2009. Artificial maturation and reproduction of the European eel. In: van de Thillart G, Dufour $\mathrm{S}$, Rankin JC (eds.). Spawning migration of the European eel: reproduction index, a useful tool for conservation management. Fish \& Fisheries Series, 30. Springer, New York, USA. pp. 309-331.

Righton D, Aarestrup K, Jellyman D, Ebert PS, Van Den Thillart G, Tsukamoto K. 2012. The Anguilla spp. migration problem: 40 million years of evolution and two millennia of speculation. Journal of Fish Bio$\log y$, 81(2):365-386.

Silfvergrip AMC. 2009. CITES identification guide to the freshwater eels (Anguillidae) with focus on the european eel Anguilla anguilla. The Swedish Environmental Protection Agency, Sweden. 135 p.

Sugeha HY, Arai T, Miller MJ, Limbong D, Tsukamoto K. 2001. Inshore migration of the tropical eels Anguilla spp. recruiting to the Poigar River estuary on north Sulawesi Island. Marine Ecology Progress Series, 221: 233-243
Tabeta O, Takai T, Matsui I. 1976a. The sectional counts of vertebrae in the anguillid elvers. Japanese Journal of Ichthyology, 22(4):195-200.

Tabeta O, Tanimoto T, Takai T, Matsui I, Imamura T. 1976b. Seasonal occurrence of anguillid elvers in Cagaya River, Luzon Island, the Philippines. Bulletin of the $\mathrm{Ja}$ panese Society of Scientific Fisheries 42(4): 421-426.

Tanaka H, Kagawa H, Ohta H, Unuma T, Nomura K. 2003. The first production of glass eel in captivity: fish reproductive physiology facilitates great progress in aquaculture. Fish Physiology and Biochemistry, 28(1-4):493-497.

Tesch FW. 2003. The eel. Blackwell Science Ltd, Oxford, UK. $418 \mathrm{p}$

Usui A. 1976. Eel culture. Fishing News Books Ltd. West Byfleet, England. 186 p.

Watanabe S, Aoyama J, Tsukamoto K. 2009. A new species of freshwater eel Anguilla luzonensis (Teleostei: Anguillidae) from Luzon Island of the Philippines. Fisheries Science, 75(2):387-392.

Watanabe S, Aoyama J, Hagihara S, Ai B, Azanza RV, Tsukamoto K. 2013. Anguilla huangi Teng, Lin, and Tzeng, 2009, is a junior synonym of Anguilla luzonensis Watanabe, Aoyama, and Tsukamoto, 2009. Fisheries Science, 79(3):375-383.

Wothuyzen S, Aoyama J, Sugeha HJ, Miller MJ, Kuroki M, Minegishi Y, Suharti SR, Tsukamoto K. 2009. Seasonality of spawning by tropical anguillid eels around Sulawesi Island, Indonesia. Naturwissenschaften, 96(1):153-158. 